\title{
THE MODEL OF SUPPORT AND PROMOTION SYSTEM FOR DEVELOPMENT OF THE STAFF COMPETITIVENESS IN MODERN ENTERPRISE AS LEARNING ORGANIZATION
}

\author{
Irena Katane \\ Latvia University of Agriculture \\ Institute of Education and Home Economics
}

\begin{abstract}
Since Latvia is member of the European Union, the importance of our society's competitiveness and each its member's competitiveness is becoming even more important as the society of Latvia and each individual lives in a social space and the space of the global economy. Latvia must ensure the development of a knowledge based, democratic and socially integrated society. The development of competitiveness of Latvian society and the national economy must be ensured. It has been already acknowledged that an effective means for promoting competitiveness is lifelong and lifewide education, therefore enterprises and other various institutions are becoming learning organizations that promote the professional development and competitiveness of their staff in the context of knowledge society in general. The competitiveness of an enterprise to a great extent is dependent on the support and promotion system of the staff competitiveness. The aim of the article is to make public the results of theoretical research, describing the worked out Model of Support and Promotion System for Development of the Staff Competitiveness in Modern Enterprise as Learning Organization. The designed model as such is a system of cooperation that contains four basic components of the interaction: personnel management, career counselling, mentoring and specialist's competitiveness which is a central component in this model.
\end{abstract}

Keywords: specialist's competitiveness, model of the support and promotion system, enterprise as learning organisation.

\section{Introduction}

At the end of the 20th century and in the beginning of the 21 st century increasing attention in social sciences is paid to the concept of competitiveness and its different contexts. Also more emphasis is put on the issue of a necessity to foster the development of competitiveness. The evidence to the aforesaid is the fact that the term of competitiveness is used in all levels of documentation, and also many scientists that represent different branches of science, including education sciences, have devoted their research to the substantiation and study of competitiveness, and also supporting and promotion of personality's/ specialist's competitiveness in close connection with enterprise/ organization competitiveness.

The ecological and synergetic paradigms in social sciences, including education sciences, enables to study a personality and/or organization as a self-developing, self-organizing and self-evaluating system that functions in various sphere and learns to live, plan and forecast; constructs and accumulates its own experience; that is able to choose and to be responsible for the consequences of its own actions under the conditions of modern changes. The synergetic approach 
enables to draw a conclusion that nowadays an individual and/or a organization as open (dissipative) system must learn to live and change in the interaction with the changeable environment (Katane, 2007a; Katane, 2007b).

As we can see, in the old paradigm the competitiveness more often is related to the personality's success and victories over its competitor, sometimes it is related to an image of a harsh fighter, who has no mercy towards the enemy, competitor and who considers any means useful for achieving the goals. It is possible to draw the following conclusions from the substantiation of the new paradigm of competitiveness: crisis shall be attributed to all, even to the most successful entrepreneurs, the most advanced society and economy; however, to be competitive means to be able to adapt to new conditions, to overcome difficulties and to achieve more than before - before the crisis. In the new paradigm the ability to change, to live and to develop in the changeable environment is particularly important. The development of an entrepreneur's (businessman's) competitiveness nowadays is related not only to the features characteristic to a leader, but, first of all, to the socio-psychological and moral characterizing indicators, the interaction of a personality with society, attitude towards other people, oneself, duties, moral and ethical values. There are three spheres of the development of a specialist's competitiveness: 1) activity sphere; 2) the sphere of interaction with the environment, including the interaction with social environment - other people; 3) the sphere of a personality's selfdevelopment, including the self-awareness and self-determination.

The aim of article is publishing results of theoretical research: the worked out model of support and promotion system for development of the staff competitiveness in modern enterprise as learning organization.

\section{Results of Theoretical Research}

During last years the research of this article's author took place in collaboration with Gita Katana (chief specialist of corporation "Balta" in Latvia) and $\mathrm{PhD}$. Ineta Kristovska (pro-rector of University College of Economics and Culture).

Several trends of theoretical research serve as the methodological substantiation for the creation and improvement of the Model for Development and Promotion of Staff Competitiveness in Modern Enterprise as Learning Organization.

- Career Counseling (Bloch, 2004; Katane, Penķe, 2009; Goodman, Hoppin, 2007; Kuijpers, Schyns, Scheerens, 2006; Scott, Marshal, 2005; Толочек, 2005 etc.).

- Concurrentology, including substantiation of the concepts: personality's competitiveness and /specialist's competitiveness (Floren, 1998; Katane, 2010; Katane, 2011a; Katane, 2011b; Katane, Kalniņa, 2010; Katane, İriste, 2013; Peters, Waterman, 2004; Митина, 2003; Шаповалов, 2003 etc.).

- Knowledge Society (Gross, 2010; Harvey, 2010; Katane, 2007b; Sterling, 2001 etc.). 
- Learning Organisation (DeGeus, 1988; DeGeus, 1999; Garratt, 2000; Katane, Laizāne, 2012b; Leithwood, Aitken, 1995; Senge, 1990; Voulalas, Sharpe, 2005).

- Management Sciences, including Personnel Management (Atkinson, 1964; Caune, 2005; Dāvidsone, 2009; Forands, 2004; Katane, Kristovska, Katana, 2013, Katane, Laizāne, 2012b etc.).

- Mentoring (Achinstein, Akopova, 2006; Daloz, 1986; Katane, 2007c; Katane, Laizāne, 2012a; Katane, Laizāne, 2012b; Konstantinova, Rivža, 2007 etc).

The research methods: analysis and evaluation of scientific literature, modeling.

Since Latvia is member of the European Union, the importance of our society's competitiveness and each its member's competitiveness is becoming even more important as the society of Latvia and each individual lives in a social space and the space of the global economy. Latvia must ensure the development of a knowledge based, democratic and socially integrated society. The development of competitiveness of Latvian population and the national economy must be ensured. It has been already acknowledged that an effective means that would promote competitiveness is lifelong and lifewide education, therefore enterprises and other various institutions are becoming learning organisations that promote the professional development and competitiveness of their staff and knowledge and information society in general (Figure 1).

The competitiveness of an enterprise as learning organisation and the competitiveness of its staff in general to a great extent is dependent on: 1 ability, and especially the ability of its management group, to provide answers to the following questions: what this enterprise knows-how and knows-why to do best; what is different in this enterprise comparing with others; why customers choose exactly the products or services of this enterprise; what is the competitiveness of staff in this enterprise; 2) the developed model of the specialist's competitiveness support and promotion system (Figure 1).

From these statements it follows that the competitiveness of the whole society, economy and each enterprise can be ensured developing the competitiveness of each individual as a personality and professional specialist.

This means that support and promotion of the specialists' competitiveness development is the interaction system which functions in two level contexts: 1) modern enterprise as learning organisation; 2) knowledge and information society (Figure 1).

We research an enterprise as self-developing, self-organising, self-evaluating and open system of business, professional development, professional support and promotion, and also educational environment. This means that an enterprise as a learning organisation is viable system that is open for new information, able to study the processes going on in the surrounding environment, including transformational processes, can learn from the experience of others, ready to 
draw conclusions necessary for ensuring its viability and sustainability on the basis of obtained new information and new experience, and on the basis of these conclusions changes continuously. There have been advantages of viable, sustainable and competitive organisation described in the scientific literature, enabling them to become the learning organisations or knowledge organisations, because there has been studies the experience of such organisations. On the basis of the analysis of this scientific literature, there were seven basic principles identified that enable a enterprise to become a learning organisation: 1) the analysis and evaluation of environment; 2) the vision and aims; 3) cooperation; 4) taking upon the initiative and risks; 5) the control of study process; 6) recognition and enhancement; 7) the continuation of professional development, including specialists' competitiveness.

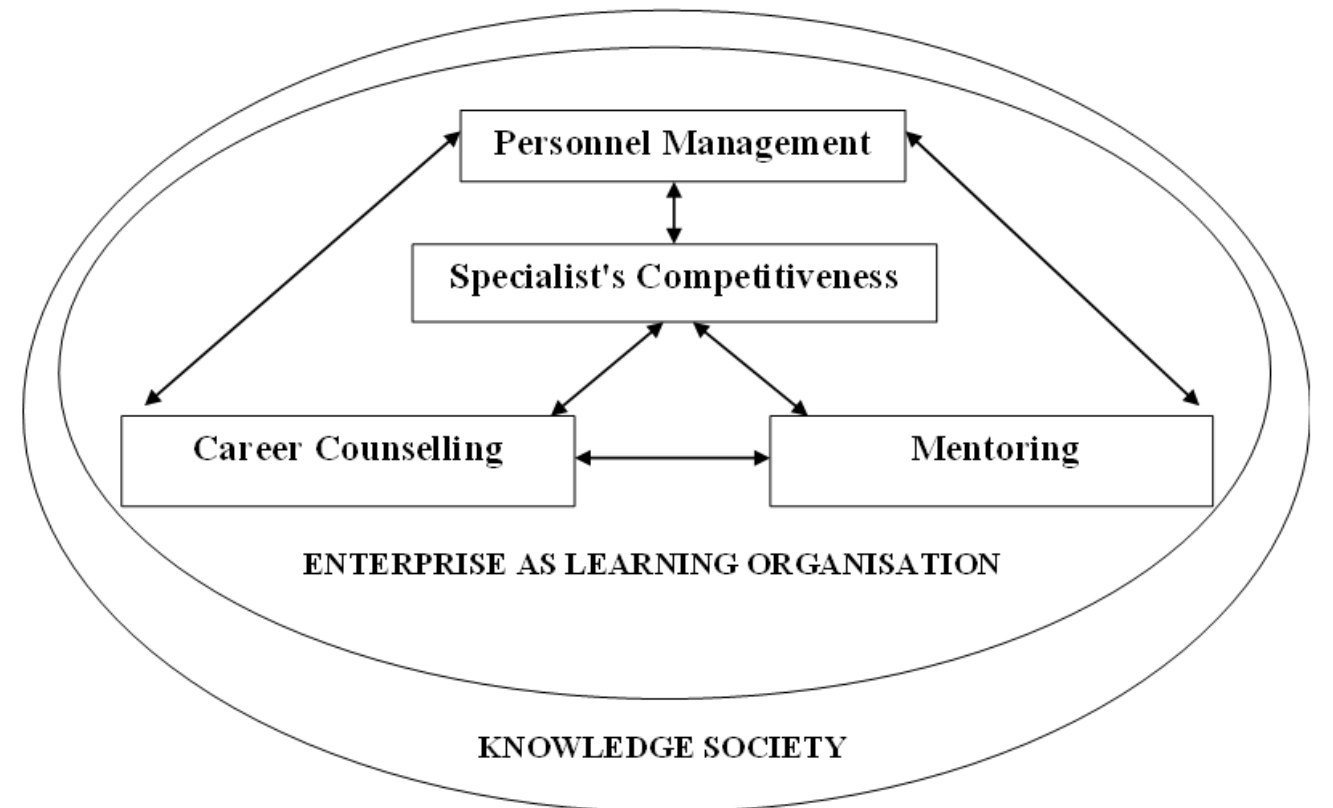

Figure 1 The model of support and promotion system for development of the staff competitiveness in modern enterprise as learning organisation (Author's design)

In developed model, knowledge society is a very broad and multidimensional concept that, according to its meaning, is very closely related to ensuring an open and multifunctional social and educational environment, were education is the important means for promotion of society's sustainable development, respecting the interests and needs of whole society and supplying a lifelong and lifewide education for all target groups.

The author of this article have included components of personnel management, career counselling and mentoring in this model, that during mutual interaction create the system of promotion and support for the development of specialist's competitiveness in an enterprise as learning/ knowledge organisation. The aim of this system is to provide appropriate and friendly environment for the professional development of specialists, therefore the specialist of an enterprise 
with his/her competitiveness is placed in the centre of the model, that emphasises the aim that directs the functioning of the whole system: to cooperate with each specialist in the enterprise in order to support and promote his/her professional development, including competitiveness' development (Figure 1).

In order to support and promote the development of specialist's competitiveness in an enterprise, in the beginning it is important to answer the following questions: What is competitiveness? What is the methodological basis for the promotion and assessment of competitiveness? Answer to these questions can be given studying results of research performed in the field of concurrentology. It is possible to observe two tendencies in the substantiation of a specialist's competitiveness. These tendencies are related to the liberally rational and humanistic paradigms in education: 1) scientists of economics and other disciplines, on the basis of regularities, categories, conceptions, theories of economics, try to use transfers for the development of the definitions of a specialist's competitiveness; 2) the representatives of pedagogy and psychology sciences develop the substantiation of a personality's competitiveness and/or a specialist's competitiveness on the basis of humanistic and ecological approach in education. The competitiveness of a specialist is related to his marketability and employability in the labor market.

The double pointed arrows that can be seen in the model between the components of the system show that in each organisation (enterprise) there must be a cooperation between the representatives of personnel management, career counselling and mentoring, who working as a team can fulfil the main aim of this system of cooperation and perform their functions.

The system of promotion and support for the development of specialist's competitiveness in learning organisation (an enterprise) must provide openness and accessibility of information about the development strategy of the enterprise, personnel policy in the enterprise, must help to identify the opportunities for the career advancement, emphasizing the sphere of motivation for the advancement of the career, must provide psychological support during the process of shaping and stabilizing self-esteem, self-respect that is adequate to professional competences and the level of abilities. The process of adopting and exchanging the best experience in the enterprise must be maintained, also programmes for professional development and further education must be planned and offered to employees both in the enterprise and also showing opportunities outside it.

The Model of for Development of the Staff Competitiveness in Modern Enterprise as Learning Organization consists of two parts: 1) the figure of system organising the support and promotion of specialist's competitiveness in the organisation (Figure 1); and 2) description of support and facilitation 
functions in the framework of three various areas - system's components (Figure 2; Addition: Table 1).

To achieve successful functioning of the system, within the model of system of promotion and support for the development of specialist's competitiveness in an organisation (enterprise), the author of the article have devised a detailed description of functions performed by each component of the system. (Addition: Table 1).

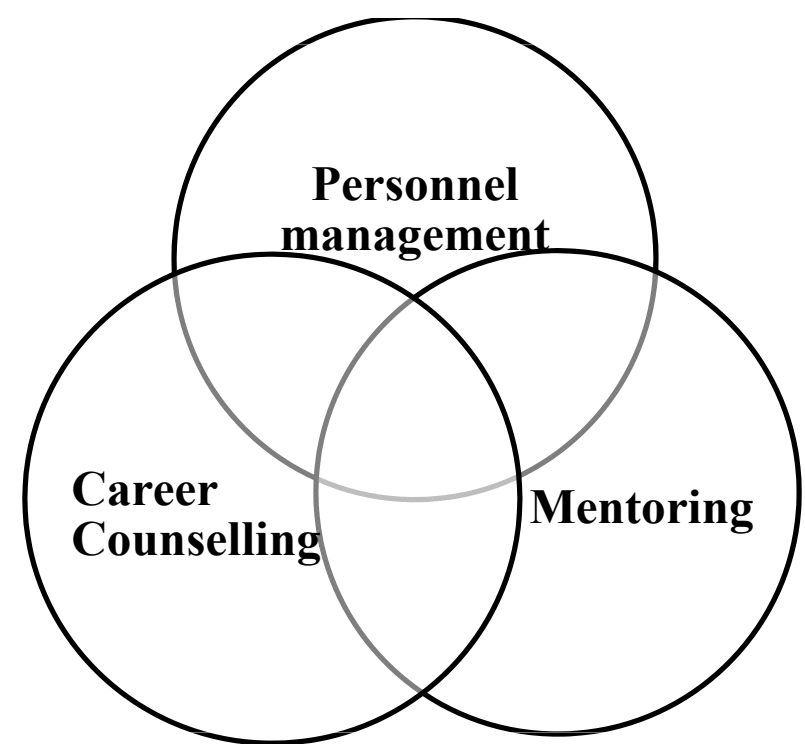

Figure 2 Segments of components in the system of promotion and support for the development of specialist's competitiveness in a learning organisation (Author's design)

As it can be seen in Figure 2, the functions of personnel management, career counselling and mentoring differ due to the specificity of each sphere, but also mutually complement each other, showing that the functional segments of these spheres partially overlap.

\section{Conclusions}

The ecological and synergetic approaches enable to draw a conclusion that nowadays an individual and/or a organization as open (dissipative) system must learn to live and change in the interaction with the changeable environment. Therefore we research an enterprise as self-developing, self-organising, selfevaluating and open system of business, professional development, professional support and promotion, and also educational environment. This means that an enterprise as a learning organisation is viable system that is open for new information, able to study the processes going on in the surrounding environment, including transformational processes, can learn from the experience of others, ready to draw conclusions necessary for ensuring its viability and sustainability on the basis of obtained new information and new experience, and on the basis of these conclusions changes continuously. 
The competitiveness of enterprise to a great extent is dependent on each employee's as specialist's competitiveness, therefore it is important to promote the specialists' competitiveness development in enterprises.

The promotion and support system for the development of specialists' competitiveness in an enterprise (organization) must provide openness and accessibility of information about the development strategy of the enterprise, personnel policy in the enterprise, must help to identify the opportunities for the career advancement, emphasizing the sphere of motivation for the advancement of the career, must provide psychological support during the process of shaping and stabilizing self-esteem, self-respect that is adequate to professional competences and the level of abilities. It is important to develop support and promotion system for development of the staff competitiveness in modern enterprise as learning organisation in the context of knowledge society.

The Model of Support and Promotion System for Development of the Staff Competitiveness in Modern Enterprise as Learning Organization consists of two parts: 1) the figure of system organising the support and promotion of specialist's competitiveness in an enterprise as learning organisation in the context of knowledge society; 2) the detailed description of support and promotion system's components - areas, there are various functions in each component.

\section{References}

1. Achinstein, B., Athanases, S.R. (2006).Mentors in the making. New York: Tachers College Press.

2. Atkinson, J.W. (1964). An introduction to motivation // Oxford, England: Van Nostrand.

3. Bloch, D. P. (2004). Spirituality, Complexity, and Career Counseling. In Professional School Counseling. USA, ASCA, p. 343-350. Retreived Juny 12, 2013 from: http://www.johnhawkinslpc.com/PDF/Spirituality/Career\%20Counseling.pdf .

4. Caune J. (2005). Konkurētspējīgās priekšrocības radī̌̌anas, attīstī̌sanas un pārnešanas metodika Latvijas uzñēmumos (Methodology of creating, developing and transfering of competitive advantage in Latvian companies). Promocijas darbs. Rīga: LU, 188 lpp. (in Latvian).

5. Daloz, L. (1986). Effective teaching and mentoring. San Francisco: Jossey-Bass, $256 \mathrm{pp}$.

6. Dāvidsone, G. (2008). Organizāciju efektivitātes modelis (Organizational Efficiency Model). Rīga: SIA O.D.A. (in Latvian)

7. DeGeus, A. (1999). The Living Company. London: Nicholas Brealey Publication, pp. 225-226.

8. DeGeus, A. (1988). Planning as learning. Harvard Business Review, March/April, pp. 70-74.

9. Floren, G. L. (1998). Marketable skills and attitudes. MiraCosta College, California. Retrieved November 9, 2013 from: http://www.miracosta.edu/home/gfloren/ market.htm\#Careers.

10. Forands, I. (2004). Personāla vadība (Personnel Management). Rīga: Latvijas izglītības fonds, 189 lpp. (in Latvian)

11. Garratt, B. (2000). Learning organization: developing democracy at work. Wondon: Harper Collins Business, 137 pgs. 
12. Goodman, J., Hoppin, J. (2007). Adult Career Counseling: New Clients, New Strategies (ACAPCD-10). Alexandria, VA: American Counseling Association. Retreived May 6, 2013 from: http://counselingoutfitters.com/vistas/ACAPCD/ACAPCD-10.pdf.

13. Gross, M. (2010). Ignorance and Surprise: Science, Society, and Ecological Design. Cambridge, MA: MIT Press.

14. Harvey, P.L. (2010). Applying social systems thinking and community informatics thinking in education. In Rudestam, K.E., Schoenholtz-Read, J. (Eds.). Handbook of online learning. Thousand Oaks, CA: Sage Publications, Inc., pp. 91-128.

15. Katane, I. (2011a). Methodological Bases for Evaluation of Specialist Competitiveness. In Proceedings of the $10^{\text {th }}$ International Scientific Conference Engineering for Rural Development, Vol. 9 (May 26-27, 2011). Jelgava: LLU, pp. 524 - 529. Retrieved March 9, 2014 from: http://tf.llu.lv/conference/proceedings2011/Papers/097_Katane.pdf

16. Katane, I. (2011b). Philosophic Methodological Bases for Evaluation of Educator's Competitiveness. In Proceedings of the 17th Annual International Scientific Conference Science for Rural Development, Vol. 2 (May 18-20, 2011). Jelgava: LLU, pp. 218 - 224. Retrieved March 9, 2014 from: http://www.llu.lv/getfile.php?id=44019.

17. Katane, I. (2010). Competitiveness of Personality as a New Concept in Modern Education and Pedagogy. In Proceedings of the $9^{\text {th }}$ International Scientific Conference Engineering for Rural Development (May, 27-28, 2010). Jelgava: LLU, pp. 324 - 334. Retrieved March 9, 2014 from: http://tf.llu.lv/conference/proceedings2010/ Papers/62_Katane_Irena.pdf.

18. Katane I. (2007a). No ekologiskās paradigmas lìdz vides modelim izglītības pètniecībā (From Ecological Paradigm till Environmental Model in the Research of Education). Monogrāfisko pētījumu sērija Izglītības ekologija. Jelgava, LLU, 239 lpp. (In Latvian)

19. Katane I. (2007b) Paradigmas Latvijas izglītîbas vidē mūsdienās (Paradigms in the Latvian Education Environment Nowadays). Sērija „Izglītības ekologija”. Jelgava: LLU TF IMI, 117 lpp. (In Latvian)

20. Katane, I. (2007c). Systemic ecological approach in teacher education: Ecological didactic model of students' pedagogical practice Journal of Teacher Education for Sustainable Development, Vol. 2 (7), pp. 40- 54.

21. Katane I., İriste S. (2013). Students' as Prospective Hospitality Specialists' Competitiveness in Theory and Practice. In Proceedings of the International Scientific Conference Society. Integration. Education (May 24-25, 2013, Latvia). Rēzekne: RA, pp. 119-129.

22. Katane, I., Kalniņa, I. (2010). Skolēnu konkurētspējas attīstība neformālās komercizglìtības vidē (The Development of Secondary School Pupils' Competitiveness within the Environment of Non-Formal Commercial Education). Jelgava: LLU TF IMI, 331 pgs. (in Latvian).

23. Katane, I., Laizāne, A. (2012). Cross-School Mentoring as a Facilitator of Sustainable Development of Rural Schools in Latvia. In Proceedings of the International Scientific Conference Rural Environment. Education. Personality. (March 21 - 22, 2012). Latvia, Jelgava: LLU, pp. $43-50$.

24. Katane I., Laizāne A. (2012b). Divdesmit pirmā gadsimta lauku skolas izglītības vide Latvijā un ārzemēs (Educational Environment of the 21st Century's Rural School in Latvia and abroad). Sērija „Izglītîbas ekologija”. Jelgava: LLU TF IMI, 284 lpp. (in Latvian)

25. Katane, I., Penķe, D. (2009). Gender accordance principle in career education in the context of ecological approach. Proceedings of the International Scientific Conference Rural Environment. Education. Personality. Jelgava: LLU TF IMI, pp. 305. - 316. 
26. Konstantinova, E., Rivža, B. (2007). Mentoringa kustības rokasgrāmata (Handbook of Merntoring Movement). Jelgava: Latvijas Lauksaimniecības universitāte. Retrieved 12.12.2013 from: http://www.llsa.lv/mentoringa_gr.pdf. (in Latvian)

27. Kuijpers, M.A.C.T., Schyns, B., Scheerens, J. (2006). Career Competencies for Career Success. The Career Development Quarterly, 55, pp. 168 - 175. Retrieved October 4, 2012 from: http://www.utwente.nl/igs/tccr/tccr\%20publicaties/kuijpers_schyns_ scherens2006.pdf

28. Peters, T., Waterman, R. (2004). In Search of Excellence: Lessons from America's Bestrun Companies. New York: Harper Business Essentials, 400 pp.

29. Scott, J., Marshall, G. (eds.). (2005). Oxford Dictionary of Sociology: Third Edition. NY: Oxford University Press, 720 pp.

30. Sterling, S. (2001). Susatainable Education. Re-visioning Learning and Change. Schumacher Breifing No. 6. Publisher by Green Books, 96 pp.

31. Митина, Л. М. (2003). Психология развития конкурентоспособной личности (Developmental Psychology pf the competitive personality). Москва: МПСИ, 400 с. (in Russian).

32. Толочек, В.А. (2005). Современная психология труда (Modern Labor Psychology). Москва: ПИТЕР, p. 479 (in Russian).

33. Шаповалов, В. И. (2003). Формируем конкурентоспособную личность (Formation of the Competitive Personality). Школьные технологии, 3, pp. 38-44 (in Russian).

Addition

Table 1

The functions of the system for the support and promotion of staff competitiveness

\begin{tabular}{|c|c|c|}
\hline $\begin{array}{c}\text { Career counselling functions in the } \\
\text { enterprise }\end{array}$ & $\underset{\text { management }}{\text { functions }}$ & Mentoring functions \\
\hline $\begin{array}{l}\text { Information is provided about the } \\
\text { situation in the labour market, the } \\
\text { trends in the development of the labour } \\
\text { market, the requirements of the labour } \\
\text { market, opportunities for acquisition of } \\
\text { education in Latvia and abroad }\end{array}$ & $\begin{array}{l}\text { Devising and } \\
\text { implementation of } \\
\text { enterprise } \\
\text { development strategy } \\
\text { and/ or conception in } \\
\text { the regional, national } \\
\text { and international level }\end{array}$ & \begin{tabular}{l}
\multicolumn{3}{c}{ Creation and provision of } \\
optimal conditions for \\
the exchange of \\
experience in the \\
enterprise
\end{tabular} \\
\hline $\begin{array}{l}\text { Information is provided about } \\
\text { personnel management policy in the } \\
\text { enterprise, the system of monitoring, } \\
\text { control, assessment, promotion of staff } \\
\text { professional performance and the } \\
\text { system of remuneration in the } \\
\text { enterprise }\end{array}$ & $\begin{array}{l}\text { Planning of human } \\
\text { resources, staff } \\
\text { selection and } \\
\text { recruitment }\end{array}$ & $\begin{array}{l}\text { Integration of new } \\
\text { specialists in the } \\
\text { enterprise and promotion } \\
\text { and fostering of } \\
\text { successful professional } \\
\text { performance }\end{array}$ \\
\hline
\end{tabular}


Continuation of the Table 1

\begin{tabular}{|c|c|c|}
\hline $\begin{array}{c}\text { Career counselling } \\
\text { functions in the } \\
\text { enterprise }\end{array}$ & $\begin{array}{l}\begin{array}{c}\text { Personnel management } \\
\text { functions }\end{array} \\
\longrightarrow \quad\end{array}$ & Mentoring functions \\
\hline $\begin{array}{l}\text { Provision of individual } \\
\text { consultations about } \\
\text { career advancement } \\
\text { opportunities in the } \\
\text { enterprise, motivation } \\
\text { and encouraging }\end{array}$ & $\begin{array}{l}\text { Administration of staff, } \\
\text { record keeping }\end{array}$ & $\begin{array}{l}\text { The support and strengthening of } \\
\text { new specialists' motivation }\end{array}$ \\
\hline $\begin{array}{l}\text { Assistance in career } \\
\text { planning-guidance, } \\
\text { incl. promotion of } \\
\text { lifelong career planning }\end{array}$ & $\begin{array}{l}\text { Provision of information } \\
\text { exchange, incl. both vertically } \\
\text { (between the supervisor and } \\
\text { the subordinates) and } \\
\text { horizontally (between } \\
\text { employees) }\end{array}$ & $\begin{array}{l}\text { Encouraging new specialists to } \\
\text { grow professionally, providing } \\
\text { welfare, personality development } \\
\text { and the quality of learning }\end{array}$ \\
\hline $\begin{array}{l}\text { Career counselling; } \\
\text { individual and group } \\
\text { counselling }\end{array}$ & $\begin{array}{l}\text { Monitoring and control of } \\
\text { staff performance in the } \\
\text { enterprise }\end{array}$ & $\begin{array}{l}\text { Support and promotion of lifelong } \\
\text { education for enterprise staff in } \\
\text { different age groups }\end{array}$ \\
\hline $\begin{array}{l}\text { Provision of career } \\
\text { education in the } \\
\text { enterprise }\end{array}$ & $\begin{array}{l}\text { Assessment of professional } \\
\text { performance }\end{array}$ & $\begin{array}{l}\text { To plan, supervise and coordinate } \\
\text { the process of education and } \\
\text { further education, turning the } \\
\text { enterprise into an organisation that } \\
\text { is learning. }\end{array}$ \\
\hline $\begin{array}{l}\text { Organising of } \\
\text { competition, election } \\
\text { for a post and/or } \\
\text { candidates for the post }\end{array}$ & $\begin{array}{l}\text { Fostering of staff's } \\
\text { professional development }\end{array}$ & $\begin{array}{l}\text { Popularisation of the best work } \\
\text { experience, incl. personal } \\
\text { experience, in the enterprise }\end{array}$ \\
\hline $\begin{array}{l}\text { The creation of } \\
\text { professional profiles for } \\
\text { the staff in the } \\
\text { enterprise and } \\
\text { candidates for } \\
\text { vacancies }\end{array}$ & $\begin{array}{l}\text { Fostering and support for } \\
\text { professional education and } \\
\text { further education }\end{array}$ & $\begin{array}{l}\text { Expansion of cooperation between } \\
\text { enterprises (employers) and } \\
\text { providers of education }\end{array}$ \\
\hline $\begin{array}{l}\text { Assessment of } \\
\text { professional suitability }\end{array}$ & $\begin{array}{l}\text { Development and } \\
\text { implementation of } \\
\text { remuneration system in the } \\
\text { enterprise }\end{array}$ & $\begin{array}{l}\text { Introduction of generation renewal } \\
\text { traditions, their promotion, } \\
\text { development and maintaining of } \\
\text { cooperation culture }\end{array}$ \\
\hline $\begin{array}{l}\text { Organisation and } \\
\text { monitoring of trial } \\
\text { work }\end{array}$ & $\begin{array}{l}\text { Implementation and control } \\
\text { of rules set in the statutes of } \\
\text { the enterprise }\end{array}$ & $\begin{array}{l}\text { Provision of experience exchange } \\
\text { between specialists of different } \\
\text { age in order to provide } \\
\text { professional development }\end{array}$ \\
\hline $\begin{array}{l}\text { Helping staff to acquire } \\
\text { an ability of staying in } \\
\text { the position }\end{array}$ & $\begin{array}{l}\text { Regulation of mutual } \\
\text { relationship among the staff } \\
\text { within the limits of enterprise } \\
\text { statutes }\end{array}$ & $\begin{array}{l}\text { Protection and support for the } \\
\text { monitored }\end{array}$ \\
\hline
\end{tabular}


Continuation of the Table 1

\begin{tabular}{|c|c|c|}
\hline $\begin{array}{c}\text { Career counselling } \\
\text { functions in the } \\
\text { enterprise }\end{array}$ & $\rightarrow \quad \begin{array}{c}\downarrow \\
\text { Punctions }\end{array}$ & Mentoring functions \\
\hline $\begin{array}{l}\text { Assessment of staff } \\
\text { competitiveness and } \\
\text { measures and support for } \\
\text { its improvement }\end{array}$ & $\begin{array}{l}\text { Provision of conditions in the } \\
\text { enterprise that are necessary } \\
\text { for professional performance, } \\
\text { incl. care about safety at } \\
\text { work, safe working } \\
\text { environment in the enterprise }\end{array}$ & $\begin{array}{l}\text { Initiation of different } \\
\text { improvements and changes in } \\
\text { the enterprise }\end{array}$ \\
\hline $\begin{array}{l}\text { Cooperation with } \\
\text { psychologist in the } \\
\text { enterprise or outside it, } \\
\text { incl. organisation of } \\
\text { psychologist's } \\
\text { consultations for the staff }\end{array}$ & $\begin{array}{l}\text { Provision of social care and } \\
\text { health care for the staff }\end{array}$ & $\begin{array}{l}\text { Maintaining and continuing of } \\
\text { enterprise's culture traditions }\end{array}$ \\
\hline $\begin{array}{l}\text { Prevention of } \\
\text { occupational burnout and } \\
\text { provision of } \\
\text { psychotherapy for those } \\
\text { who are in need of it }\end{array}$ & $\begin{array}{l}\text { Motivation, furthering of } \\
\text { loyalty, promotion of positive } \\
\text { attitude towards the work }\end{array}$ & $\begin{array}{l}\text { Expanding of opportunities for } \\
\text { staff's leisure time activities, } \\
\text { involving into education of } \\
\text { interest or non-formal education }\end{array}$ \\
\hline $\begin{array}{l}\text { Work on the } \\
\text { improvement of career } \\
\text { consultation } \\
\text { methodology, } \\
\text { approbation and } \\
\text { implementation of new } \\
\text { methods in the enterprise }\end{array}$ & Making staff feel stability & $\begin{array}{l}\text { Openness towards dialogue and } \\
\text { cooperation; provision of } \\
\text { psychological and professional } \\
\text { support to the monitored }\end{array}$ \\
\hline $\begin{array}{l}\text { Cooperation with the } \\
\text { management of the } \\
\text { enterprise, mentors of the } \\
\text { enterprise and other } \\
\text { specialists }\end{array}$ & $\begin{array}{l}\text { Provision of gradual renewal } \\
\text { of generations in the } \\
\text { enterprise }\end{array}$ & $\begin{array}{l}\text { Performing of mediator's } \\
\text { functions in case of necessity } \\
\text { between: 1)the employee and } \\
\text { the monitored; 2) the monitored } \\
\text { and colleagues }\end{array}$ \\
\hline $\begin{array}{l}\text { Development and } \\
\text { coordination of a group } \\
\text { for career support and } \\
\text { provision of professional } \\
\text { growth of enterprise } \\
\text { staff. }\end{array}$ & $\begin{array}{l}\text { To ensure the exchange of } \\
\text { experience, involvement of } \\
\text { enterprise staff into different } \\
\text { projects, also international }\end{array}$ & $\begin{array}{l}\text { Fostering of cooperation } \\
\text { between different specialists in } \\
\text { the enterprise }\end{array}$ \\
\hline
\end{tabular}

$\mathrm{PhD}$, assoc. Professor

\section{Irēna Katane}

Latvia University of Agriculture, Institute of Education and Home Economics e-mail: irena.katane@inbox.lv 